\title{
PENERAPAN MODEL PEMBELAJARAN NUMBERED HEAD TOGETHER MENINGKATKAN HASIL BELAJAR IPA SISWA KELAS IV SD NO. 3 KAPAL
}

\author{
Ni Km. Suandewi 1,*, I Made.Citra Wibawa ${ }^{2}$ \\ 1 Jurusan Pendidikan Guru Sekolah Dasar. Universitas Pendidikan Ganesha, Indonesia \\ 2 Jurusan Pendidikan Guru Sekolah Dasar. Universitas Pendidikan Ganesha, Indonesia
}

\begin{abstract}
Abstrak
Penelitian ini bertujuan untuk mengetahui hasil belajar IPA pada penerapan model pembelajaran kooperatif Tipe Numbered Head Together (NHT) pada siswa kelas IV SD No. 3 Kapal tahun pelajaran 2016/2017. Penelitian ini adalah penelitian tindakan kelas yang dilaksanakan dalam dua siklus. Setiap siklus terdiri atas tahap perencanaan, pelaksanaan tindakan, observasi/evaluasi, dan refleksi. Subjek penelitian ini adalah siswa kelas IV di SD No. 3 Kapal, sebanyak 37 orang siswa. Data yang dikumpulkan dianalisis dengan menggunakan metode tes. Data yang didapatkan dari metode tes selanjutnya dianalisis dengan teknik deskriptif kuantitatif. Hasil penelitian menunjukan bahwa pembelajaran IPA dengan menggunakan model pembelajaran kooperatif tipe Numbered Head Together (NHT) dapat meningkatkan hasil belajar siswa kelas IV di SD No. 3 Kapal tahun pelajaran 2016/2017. Pada siklus I rata-rata hasil belajar IPA siswa sebesar $72,70 \%$ pada kategori sedang dan meningkat menjadi $85,13 \%$ pada siklus II yang berada pada kategori tinggi. Terjadi peningkatan sebesar $12,43 \%$..
\end{abstract}

Keywords:

Model pembelajaran

NHT, hasil belajar IPA

\section{Pendahuluan}

Pendidikan memegang peranan sangat penting dalam dinamika kehidupan bangsa. Majunya pendidikan akan menunjukkan kemajuan suatu bangsa, begitu pula mundurnya pendidikan akan menjerumuskan bangsa kepada kebodohan dan kemiskinan. Pendidikan yang ideal tidak hanya berorientasi pada masa lalu dan kini, tetapi sudah seharusnya merupakan proses yang mengantisipasi dan membicarakan masa depan. Pembangunan diarahkan dan bertujuan untuk mengembangkan sumber daya manusia yang berkualitas dan pembangunan sektor ekonomi yang satu dengan lainnya saling berkaitan dan berlangsung dengan berbarengan. Proses pendidikan harus diikuti dengan kegiatan bimbingan, pengajaran atau latihan agar mampu menghadapi masa yang akan datang.

Dalam rangka mewujudkan tujuan tersebut, diperlukan berbagai upaya aktif dari pendidik dalam proses pembelajaran yang efektif dan berdaya guna. Proses belajar mengajar mengandung serangkaian perbuatan pendidikan/guru dan siswa atas dasar hubungan timbal balik yang berlangsung dalam situasi edukatif untuk mencapai tujuan tertentu. Interaksi atau hubungan timbal balik antara guru dan siswa merupakan syarat utama bagi berlangsungnya proses belajar mengajar. Hasil belajar siswa yang tinggi dalam proses pembelajaran diperlukan dalam setiap mata pelajaran, salah satunya dalam pembelajaran IPA. Mata pelajaran Ilmu Pengetahuan Alam (IPA) merupakan salah satu mata pelajaran yang harus diajarkan di sekolah dasar sesuai dengan kurikulum pendidikan sekolah dasar. Dalam proses pembelajaran IPA lebih menitik beratkan pada serangkaian proses penyelidikan tentang suatu konsep peristiwa yang terjadi di sekitar siswa. Begitu pentingnya pembelajaran IPA dalam kehidupan, seharusnya mata pelajaran IPA menjadi mata pelajaran yang menarik. Tetapi masih banyak siswa yang tidak menyukai pelajaran ini, karena beranggapan terlalu banyak menghapal sesuatu yang tidak penting.

Nur, dkk. (1996) menyatakan bahwa IPA hendaknya tidak hanya mementingkan penguasaan siswa terhadap fakta, konsep, dan prinsip-prinsip, tetapi lebih mementingkan agar siswa mengerti fakta, konsep, dan prinsip-prinsip tersebut ditemukan. Perencanaan dan pelaksanaan pembelajaran IPA di SD hendaknya selalu dikaitkan pada salingtekmas (sains, lingkungan, teknologi, dan masyarakat).

\footnotetext{
* Corresponding author.

E-mail Addresses: mangsuandewi@gmail.com (Ni Km. Suandewi), dekwi_petiga@yahoo.com (I Made.Citra Wibawa)
} 
Suryanto (2005) yang menyatakan bahwa "IPA diajarkan di kelas dapat: 1) mengembangkan kognitif siswa, 2) mengembangkan afektif siswa, 3) mengem bangkan psikomotorik siswa, 4) mengembangkan kreativitas siswa, 5) melatih siswa berfikir kritis".

Upaya untuk meningkatkan hasil belajar siswa, guru diharapkan mewujudkan suasana belajar yang relevan serta menciptakan proses pembelajaran yang berkualitas dengan mengadakan pembaharuan dalam model, metode, pendekatan, serta penggunaan media dan alat peraga dalam proses pembelajaran yang memungkinkan siswa dapat belajar secara aktif dan menyenangkan. Keberadaan peran dan fungsi guru merupakan salah satu faktor yang sangat signifikan dalam proses belajar mengajar. Guru merupakan bagian terpenting dalam proses belajar mengajar, di jalur pendidikan formal, informal, atau nonformal. Oleh sebab itu, dalam setiap upaya peningkatan kualitas pendidikan di tanah air, guru tidak dilepaskan dari berbagai hal yang berkaitan dengan eksistensi mereka.

Sudjana (2000) mengemukakan bahwa hasil belajar adalah hasil yang diperoleh setelah mempelajari materi yang diwujudkan melalui perubahan pada diri siswa tersebut yang meliputi perubahan reaksi dan sikap siswa secara fisik maupun mental. Menurut Taksonomi Bloom (Elvin, 1999) mengemukakan 3 (tiga) komponen yang dapat ditinjau dari hasil belajar, yaitu kemampuan : Kognitif (Pengetahuan), Afektif (Sikap), Psikomotorik (Keterampilan)

Menurut Hamalik dalam (Nursiyem,2012) menjelaskan bahwa "hasil belajar adalah pola perbuatan, nilai, pengertian, sikap, apresiasi, abilitas dan keterampilan". Hasil belajar belajar dibagi atas 3 macam yaitu keterampilan dan kebiasaan, pengetahuan dan pengertian, sikap dan cita-cita yang masingmasing digolongkan dapat diisi dengan bahan yang ada pada kurikulum sekolah Nana Sujana (dalam Mitrawati 2010).

Berdasarkan pengalaman mengajar di kelas IV SD No. 3 Kapal dalam proses pembelajaran IPA permasalahan yang sering muncul di kelas antara lain: 1) masih menggunakan model pembelajaran konvensional dalam membelajarkan siswa. Hal ini mengakibatkan siswa menjadi pasif karena pembelajaran didominasi oleh guru. Pembelajaran seperti ini membuat siswa tidak termotivasi untuk mengikuti proses pembelajaran karena mereka beranggapan bahwa materi yang diajarkan terlalu abstrak dan sulit untuk dimengerti, 2) dalam mengajar hanya menggunakan satu sumber belajar. Hal tersebut mengakibatkan kemampuan siswa menjadi terbatas sehingga berdampak pada rendahnya hasil belajar IPA siswa, 3) sulit melibatkan siswa secara aktif dalam proses pembelajaran sehingga aktivitas siswa menjadi pasif, 4) sebagian besar siswa menganggap bahwa IPA adalah pelajaran menghapal, membosankan, dan kurang menantang. Hal tersebut mengindikasikan bahwa guru memperkenalkan IPA hanya sebatas dimensi produk saja, dengan mengabaikan dimensi proses dan dimensi sikap ilmiah, dan 5) siswa kurang dibiasakan bekerja dalam kelompok (jarang belajar kooperatif) sehingga terdapat kecenderungan yang pintar akan semakin pintar dan yang kurang akan semakin kehilangan kesempatan untuk mengembangkan kompetensi yang dimilikinya. Ini disebabkan karena tidak adanya sharing pendapat atau diskusi terhadap suatu permasalahan. Hal ini diperkuat dengan hasil ulangan harian dilaksanakan pada tanggal 24 Agustus 2016 dengan rata-rata hasil ulangan harian mata pelajaran IPA 62,57 yang belum memenuhi KKM yang ditentukan yaitu 74, hal ini dapat dilihat sebanyak 20 siswa dari 37 siswa berada di bawah KKM. Sehingga hasil belajar IPA siswa kelas IV SD No. 3 Kapal masih tergolong rendah.

Guru harus berupaya membangkitkan motivasi siswa agar lebih aktif dalam proses pembelajaran dengan menerapkan model pembelajaran yang melibatkan siswa secara aktif dalam proses belajar mengajar. Salah satu model pembelajaran yang dapat digunakan guru adalah model pembelajaran kooperatif tipe Numbered Head Together (NHT). Model pembelajaran kooperatif tipe Numbered Head Together (NHT) pertama kali dikembangkan oleh Spenser Kagen pada tahun 1993 untuk melibatkan lebih banyak siswa dalam menelaah materi yang tercakup dalam suatu pelajaran dan mengecek pemahaman mereka terhadap isi pelajaran tersebut (Trianto, 2007). Model pembelajaran kooperatif tipe Numbered Heads Together (NHT) merupakan salah satu tipe modelpembelajaran kooperatif yang dikembangkan oleh Spenser Kagen (dalam Trianto, 2009) untuk melibatkan semua anggota kelompok dalam menyelesaikan

Menurut Nur (2005) pembelajaran kooperatif tipe NHT pada dasarnya merupakan sebuah variasi diskusi kelompok dengan ciri khasnya adalah guru hanya menunjuk seorang siswa untuk mewakili kelompoknya tanpa memberitahukan terlebih dahulu siapa yang akan mewakili kelompoknya tersebut. Sehingga cara ini menjamin keterlibatan total semua siswa. Menurut Anita Lie (2008) mengemukakan bahwa model pembelajaran kooperatif tipe Numbered Heads Together (NHT) memberikan kesempatan kepada siswa untuk saling membagikan ide-ide dan mempertimbangkan jawaban yang paling tepat, selain itu model pembelajaran kooperatif tipe Numbered Heads Together (NHT) juga mendorong siswa untuk meningkatkan semangat bekerjasama mereka. 
Menurut Dina Hidayatul (2012), menyatakan bahwa model pembelajaran kooperatif tipe Numbered Heads Together (NHT) adalah salah satu cara yang digunakan oleh guru agar kegiatan belajar mengajar lebih efektif dan efisien, apabila model pembelajaran kooperatif ini diterapkan maka model ini dapat melibatkan aktivitas seluruh siswa tanpa harus ada perbedaan status, melibatkan peran siswa sebagai tutor sebaya dan mengandung unsur permainan dan reinforcement selain itu memungkinkan siswa dapat belajar lebih rileks disamping menumbuhkan tanggung jawab, kejujuran, kerja sama, persaingan sehat dan keterlibatan belajar.

Pembelajaran Kooperatif tipe Numbered Head Together (NHT) merupakan salah satu tipe pembelajaran kooperatif yang menekankan pada struktur-struktur khusus yang dirancang untuk mempengaruhi pola-pola interaksi siswa dalam memiliki tujuan untuk meningkatkan penguasaan akademik (Ibrahim, 2000). Kagen menyatakan bahwa, tekhnik ini memberikan kesempatan kepada siswa untuk saling membagikan ide-ide dan mempertimbangkan jawaban yang paling tepat. Selain itu, tekhnik ini juga mendorong siswa untuk meningkatkan kerjasama mereka (Lie, 2004).

Menurut Udani (2006), ciri khas atau karakteristik lingkungan belajar model pembelajaran kooperatif tipe NHT ini adalah hanya menginginkan satu siswa mewakili kelompoknya tanpa menginformasikan sebelumnya kepada kelompok tersebut siapa yang akan mewakilinya. Ciri khas ini memastikan keterlibatan penuh dari seluruh siswa sehingga dapat meningkatkan tanggung jawab perorangan dalam kegiatan kelompok dan dapat meningkatkan saling pengertian antar siswa. Model pembelajaran kooperatif tipe Numbered Head Together (NHT) ini dapat dijadikan alternatif variasi model pembelajaran dengan membentuk kelompok heterogen, setiap kelompok beranggotakan 5 - 6 siswa, setiap anggota memiliki satu nomor. Kemudian guru mengajukan pertanyaan untuk didiskusikan bersama dalam kelompok dengan menunjuk salah satu nomor untuk mewakili kelompok. Proses pembelajaran yang terjadi, melibatkan aktivitas siswa dan guru. Sehingga diharapkan dapat meningkatkan hasil belajar siswa. Berdasarkan uraian yang telah dijabarkan, maka dilakukan penelitian yang bertujuan untuk mengetahui peningkatan hasil belajar IPA setelah menerapkan model pembelajaran kooperatif tipe Numbered Head Together (NHT) pada siswa kelas IV SD No. 3 Kapal tahun pelajaran 2016/2017 Kecamatan Mengwi, Kabupaten Badung.

\section{Metode}

Penelitian yang dilakukan ini tergolong Penelitian Tindakan Kelas (PTK). Agung (2011) menyatakan "PTK sebagai suatu bentuk penelitian yang bersifat reflektif dengan melakukan tindakantindakan tertentu agar dapat memperbaiki dan atau meningkatkan praktek-praktek pembelajaran di kelas secara lebih profesional". PTK juga memiliki peranan yang sangat penting dan strategis untuk meningkatkan mutu pembelajaran melalui suatu tindakan bermakna dengan menggunakan sebuah model pembelajaran yang diperhitungkan dapat memecahkan masalah untuk mengukur tingkat keberhasilannya.

Prosedur kegiatan pada pelaksanaan PTK ini dilaksanakan dalam dua siklus. Adapun pelaksanaannya terdiri dari 4 tahapan yang terdapat dalam Penelitian Tindakan Kelas (PTK), mengacu pada teori yang dikemukakan oleh Arikunto (2015), yaitu: (1) tahap perencanaan tindakan meliputi menyamakan persepsi dan mempersiapkan instrumen yang diperlukan dalam penelitian , (2) tahap pelaksanaan berupa penerapan model pembelajaran kooperatif tipe $N H T$, (3) tahap observasi/evaluasi dilakukan secara berkesinambungan selama pembelajaran berlangsung dan evaluasi dilaksanakan pada setiap pertemuan, (4) tahap refleksi dilakukan setiap akhir siklus.

Data penelitian ini dikumpulkan dengan menggunakan metode tes. Dalam penelitian ini tes yang digunakan berbentuk pilihan ganda yaitu suatu tes yang menuntut siswa untuk mampu mengingat materi yang telah diajarkan dan bersifat objektivitas. Menurut Agung (2010) meyatakan bahwa, "Metode tes dalam kaitannya dengan penelitian adalah cara memperoleh data yang berbentuk suatu tugas yang dilakukan atau dikerjakan oleh seseorang atau sekelompok orang yang dites (testee) dan dari tes tersebut dapat menghasilkan suatu data berupa skor (data interval)". Jadi metode tes ini digunakan untuk mengumpulkan data tentang hasil belajar IPA pada ranah kognitif siswa sehingga dari hasil belajar siswa tersebut nantinya akan digunakan sebagai acuan dalam membuat kesimpulan.

Dalam penelitian ini instrument yang digunakan untuk mengukur hasil belajar siswa adalah instrument tes. Tes yang digunakan dalam penelitian ini adalah tes obyektif bentuk soal pilihan ganda. Tes obyektif merupakan jenis tes hasil belajar yang terdiri dari soal-soal dengan jalan memilih salah satu jawaban yang dianggap benar. Soal pilihan ganda yang digunakan sebagai instrumen berjumlah 20 butir. Setiap soal yang dijawab dengan benar oleh siswa akan diberikan skor 1 dan skor 0 untuk siswa yang menjawab salah. Skor setiap butir soal akan dijumlahkan dan jumlahnya itu dibagi dengan skor maksimal 
yaitu 20 kemudian dikalikan 100 sehingga diperoleh skor hasil akhir dari siswa. Jadi tes yang dihasilkan, diharapkan mampu mengukur hasil belajar IPA.

Subjek penelitian ini adalah siswa kelas IV yang berjumlah 37 orang yang terdiri dari 22 orang laki-laki dan 15 orang perempuan dan objek dalam penelitian ini adalah hasil belajar IPA. Penelitian ini dilaksanakan pada tahun pelajaran 2016/2017 di SD No. 3 Kapal.

Teknik analisis data yang digunakan pada penelitian tindakan kelas ini adalah teknik deskriptif kuantitatif. Menurut Agung (2010) "Metode analisis deskriptif kuantitatif merupakan suatu cara pengolahan data yang dilakukan dengan jalan menyusun secara sistematis dalam bentuk angka-angka dan presentase mengenai suatu objek yang diteliti sehingga diperoleh kesimpulan umum". Data hasil penelitian dianalisis untuk memperoleh rata-rata kelas dan tingkatan hasil belajar. Hasil ini di interpetasi dan disimpulkan untuk digunakan dalam menjawab permasalahan yang telah dirumuskan. Analisis deskriptif kuantitatif ini digunakan untuk menentukan hasil belajar siswa. Analisisnya dengan cara menghitung skor masing-masing, rata-rata hasil belajar dan prosentase rata-rat hasil belajar. Untuk angka rata-rata dihitung persentasenya kemudian dikonversikan pada pedoman konversi. Adapun rumus yang digunakan yaitu Mean (M), dan persentase tingkat hasil belajar (M\%). Untuk mengetahui tingkat kategori hasil belajar IPA siswa dilakukan dengan membandingkan angka rata-rata persen (M\%) dengan kriteria Penilaian Acuan Patokan (PAP) skala lima seperti pada tabel 1

Tabel 0. Pedoman Konversi PAP Skala Lima tentang Peningkatan Hasil Belajar IPA

\begin{tabular}{cc}
\hline Persentase & Kriteria Hasil Belajar IPA \\
\hline $90 \%-100 \%$ & Sangat tinggi \\
$80 \%-89 \%$ & Tinggi \\
$65 \%-79 \%$ & Sedang \\
$55 \%-64 \%$ & Rendah \\
$0 \%-54 \%$ & Sangat rendah \\
\hline
\end{tabular}

(Agung 2010)

Dalam penelitian ini kriteria yang digunakan untuk menunjukkan keberhasilan tindakan ini adalah (1) adanya peningkatan skor hasil belajar IPA siswa dari siklus I ke siklus II, dan (2) rata-rata persentase hasil belajar siswa mencapai $80 \%$ ke atas

\section{Hasil Dan Pembahasan}

Berdasarkan tes hasil belajar yang telah dilakukan selama penelitian, diperoleh data mengenai hasil belajar IPA. Data ini dipakai untuk mengetahui persentase keberhasilan pembelajaran siswa pada masing-masing siklus. Data yang diperoleh tersebut, kemudian dianalisis menggunakan metode analisis statistik deskriptif kuantitatif dengan cara menghitung rata-rata $(M)$, menghitung rata-rata persen (M\%), dan membandingkan rata-rata persen (M\%) tersebut dengan PAP skala lima. Setelah dilakukan analisis deskriptif kuantitatif, maka diperoleh persentase keberhasilan belajar siswa pada masing-masing siklus.

Pada siklus I persentase tingkat hasil belajar siswa adalah 72,70\%. Meskipun persentase tingkat hasil belajar sudah mencapai target yang ditentukan dalam kriteria yaitu berada pada interval 65\% - 79\% dengan kategori sedang. Berdasarkan hasil analisis, maka secara klasikal penelitian pada siklus I belum berhasil karena belum memenuhi kriteria keberhasilan penelitian yaitu penelitian dikatakan berhasil bila nilai rata-rata kelas minimal 80.

Pada siklus II persentase tingkat hasil belajar adalah $85,13 \%$ berada pada interval persentase 80\%-89\%. Berdasarkan rata-rata persentase skor hasil belajar siswa tersebut, hasil belajar siswa berada pada kategori tinggi. Ini berarti bahwa hasil belajar IPA siswa pada siklus II sudah memenuhi kriteria yang ditentukan. Hal tersebut menunjukkan bahwa ketetapan ketuntasan belajar $80 \%$ sudah tercapai. Berikut ini rekapitulasi data hasil belajar siklus I dan siklus II pada tabel 2.

Tabel 2. Rekapitulasi Data Hasil Belajar

\begin{tabular}{ccccc}
\hline Jenis Data & Tindakan & PAP (\%) & Persentase & Katagori \\
\cline { 2 - 5 } & Pra Siklus & $55-64$ & $62,57 \%$ & Rendah \\
\cline { 2 - 5 } HB IPA & Siklus I & $65-79$ & $72,70 \%$ & Sedang \\
\cline { 2 - 5 } & Siklus II & $80-89$ & $85,13 \%$ & Tinggi \\
\hline
\end{tabular}


Berdasarkan tabel di atas dapat digambarkan peningkatan hasil belajar pra siklus, siklus I, dan siklus II pada gambar 2 .

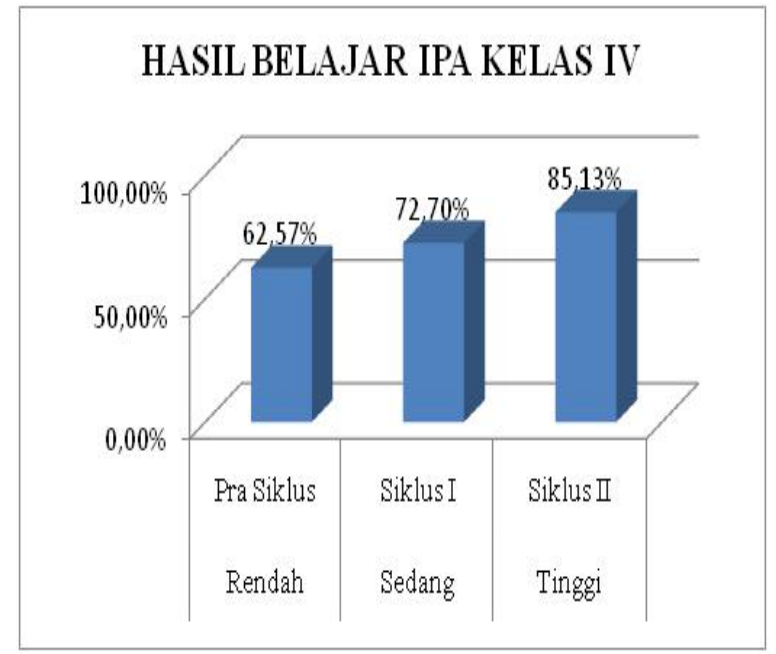

Gambar 2. Diagram Batang Hasil Belajar IPA

Sejak dilaksanakannya PTK pada siswa kelas IV SD No. 3 Kapal, banyak hal yang dapat ditemui terkait dengan kegiatan pembelajaran, mulai dari tahap pengambilan data awal sampai dengan tahap akhir pengambilan data siklus II. Pada saat pertama kali peneliti masuk kelas, peneliti hanya melakukan pengamatan terhadap hasil ulangan harian siswa. Ketika kegiatan pembelajaran berlangsung terlihat siswa kurang terfokus dalam mengikuti kegiatan pembelajaran. Pada saat kegiatan pembelajaran masih ada siswa yang ribut dan siswa yang tidak antusias dalam menerima pelajaran. Selain itu, masalah lain yang terlihat dalam kegiatan pembelajaran adalah tidak adanya media pembelajaran yang dipergunakan sehingga kurang menarik perhatian siswa dalam mengikuti pembelajaran serta metode yang digunakan hanya ceramah, tanya jawab dan diskusi, hal ini menimbulkan kesan siswa merasa bosan dan malas berdiskusi.

Berdasarkan hasil penelitian yang telah dilaksanakan selama dua siklus, menunjukkan adanya peningkatan hasil belajar siswa dengan penerapan model pembelajaran kooperatif tipe Numbered Head Together (NHT) di kelas IV SD No. 3 Kapal tahun pelajaran 2016/2017. Analisis data hasil belajar, pada siklus I diperoleh hasil yaitu rata-rata hasil belajar siswa mencapai 72,70 dan persentase nilai rata-rata siswa baru mencapai 72,70\% yang berada pada rentang skor 65-79 sehingga dapat dikategorikan sedang.

Belum tercapainya kriteria keberhasilan yang ditetapkan pada siklus I disebabkan oleh beberapa kendala yaitu: (1) Siswa belum terbiasa dengan model pembelajaran Kooperatif tipe Numbered Head Together (NHT) karena model pembelajaran ini baru pertama kali diterapkan di kelas IV. Hal ini mengakibatkan keberanian siswa dalam mengemukakan pendapat dalam proses belajar mengajar masih kurang, (2) Hubungan siswa dengan teman-teman dalam satu kelompok diskusi dalam kegiatan belajar mengajar masih kurang. Maksudnya adalah pada saat proses diskusi berlangsung ada beberapa kelompok, hanya beberapa siswa yang mengerjakan Lembar Kerja Siswa (LKS). Siswa yang lain hanya menunggu jawaban dari temannya, (3) Partisipasi dan kesungguhan siswa dalam kegiatan belajar mengajar masih kurang. Dalam proses belajar mengajar ada beberapa siswa yang tidak mau berpartisipasi dalam proses pembelajaran dan ada juga beberapa siswa yang perhatiannya lain-lain dalam proses pembelajaran berlangsung, (4) Kurangnya efektivitas pemanfaatan waktu dalam kegiatan belajar mengajar. Hal ini disebabkan karena ada beberapa kelompok dalam mengerjakan Lembar Kerja Siswa (LKS) tidak tepat waktu dan belum bisa mempresentasikan hasil diskusi kelompoknya dengan baik, dan (5) Ketika guru menunjuk salah satu nomor siswa untuk menjawab pertanyaan yang diajukan, ada beberapa siswa tidak bisa menjawab soal. Hal ini disebabkan karena aktivitas siswa dengan temannya dalam satu kelompok pada saat berpikir bersama (Head Together) tidak dimanfaatkan dengan baik.

Berdasarkan kendala-kendala yang menyebabkan belum tercapainya kriteria keberhasilan penelitian yang ditetapkan, maka diadakan penyempurnaan pada siklus berikutnya yaitu: (1) Memotivasi siswa agar lebih aktif dalam pembelajaran dan memberikan penghargaan pada kelompok yang aktif dalam mengikuti kegiatan pembelajaran, (2) Memberikan arahan kepada siswa kepada kelompok yang kurang kompak dalam mengerjakan Lembar Kerja Siswa (LKS), (3) Memberikan teguran agar siswa perhatiannya tidak lain-lain dalam proses pembelajaran berlangsung, (4) Memberikan sanksi berupa pengurangan nilai dalam kelompok jika siswa tidak tepat waktu dalam mengerjakan soal dan menyelesaikan soal, dan (5) 
Dengan menilai kekompakan kelompok. Sistem penilaian kelompok ini nantinya akan mencari kelompok yang terbaik dan diberikan reward berupa nilai tambahan dan hadiah.

Berdasarkan hasil analisis data pada siklus II maka diperoleh rata-rata hasil belajar siswa mencapai 85,13 dan persentase nilai rata-rata siswa sudah mencapai $85,13 \%$ berada dalam kategori tinggi dengan tingkat rentang ketuntasan berada pada rentang skor 80- 89. Dari analisis data pada siklus I dan siklus II di atas, diketahui bahwa hasil belajar IPA meningkat melalui model pembelajaran kooperatif tipe Numbered Head Together (NHT) pada siswa kelas IV SD No. 3 Kapal semester ganjil tahun pelajaran 2016/2017. Hal ini dapat dilihat dari rata-rata hasil belajar siswa secara klasikal pada siklus I sebesar 72,70 dengan persentase rata-rata $72,70 \%$ yang tergolong pada kategori sedang. Pada siklus II rata-rata meningkat menjadi 85,13 dengan persentase rata-rata sebesar 85,13\% yang berada dalam kategori tinggi. Seiring dengan peningkatan rata-rata hasil belajar siswa persentase rata-rata pun ikut meningkat. Peningkatan persentase rata-rata dari siklus I ke siklus II sebesar 12,43\%.

Terjadinya peningkatan hasil belajar siswa kelas IV semester ganjil pada mata pelajaran IPA disebabkan oleh pada pelaksanaan tindakan siklus II tidak lagi muncul kendala-kendala seperti pada siklus I seperti siswa sudah mulai antusias mengerjakan tugas dan berdiskusi dengan kelompoknya sehingga penguasaan materi siswa mulai ada peningkatan dan siswa sudah terbiasa dengan penerapan model pembelajaran kooperatif tipe Numbered Head Together (NHT) yang telah diterapkan oleh guru, semua siswa terlibat secara aktif dalam pembelajaran.

Pada siklus II, dalam proses pembelajaran siswa sudah terbiasa dan telah terlatih belajar dengan mengikuti penerapan model pembelajaran kooperatif tipe Numbered Head Together (NHT). Hal ini terlihat dari kegiatan yang dilakukan siswa yaitu siswa sudah terlibat aktif dalam proses pembelajaran, siswa sudah antusias dalam mengikuti pembelajaran yang dilaksanakan, sudah saling membantu antar anggota kelompok, serius dalam diskusi kelompok, berani mengajukan pertanyaan dan menyampaikan argumentasinya serta dapat mengelola waktu dengan baik. Model pembelajaran Numbered Head Together (NHT) memberikan kesempatan kepada siswa untuk bekerjasama dengan teman kelompoknya, berinteraksi sosial, dan membagikan ide-ide baru dalam kelompok bisa dikatakan seperti tutor sebaya, dimana seorang siswa memberitahukan temannya yang belum paham atau kurang mampu dalam menerima pelajaran.

Dari uraian di atas, secara umum telah mampu menjawab rumusan masalah. Penelitian ini dapat dikatakan berhasil, karena semua kriteria yang ditetapkan telah terpenuhi. Jadi, dapat dinyatakan bahwa penerapan model pembelajaran Kooperatif tipe Numbered Head Together (NHT) dapat meningkatkan hasil belajar IPA siswa kelas IV SD No. 3 Kapal tahun pelajaran 2016/2017

\section{Simpulan Dan Saran}

Berdasarkan hasil penelitian dan pembahasan yang telah diuraikan, dapat disimpulkan bahwa penerapan model pembelajaran kooperatif tipe Numbered Head Together (NHT) dapat meningkatkan hasil belajar IPA pada siswa kelas IV semester I SD No. 3 Kapal tahun pelajaran 2016/2017. Hal ini dapat dilihat dari semakin meningkatnya hasil belajar IPA pada siswa. Rata-rata persentase hasil belajar pada pra siklus sebesar $62,57 \%$ berada pada kategori rendah dan meningkat pada siklus I menjadi $72,70 \%$ berada pada kategori sedang. Terjadi peningkatan dari hasil refleksi awal ke siklus I sebesar 10,13\%. Setelah dilaksanakan perbaikan tindakan pada siklus II rata-rata persentase hasil belajar menjadi $85,13 \%$ berada pada kategori tinggi. Terjadi peningkatan rata-rata persentase hasil belajar IPA dari siklus I ke siklus II sebesar $12,43 \%$.

Berdasarkan temuan-temuan pada penelitian ini maka diajukan saran-saran: Kepada siswa SD No. 3 Kapal disarankan pada saat pembelajaran berlangsung, siswa hendaknya memfokuskan diri pada tujuan pembelajaran sehingga proses pembelajaran tidak perlu memperhatikan hal yang tidak berguna bagi pencapaian tujuan pembelajaran.

Kepada guru dan calon guru disarankan mampu memilih media pembelajaran yang dapat membantu dalam menyampaikan materi pelajaran sesuai dengan karakteristik siswa. Apabila guru ingin mengembangkan kompetensi siswa, sebaiknya guru selalu mencoba atau memilih model-model pembelajaran inovatif yang memungkinkan dapat mengembangkan kompetensi yang diinginkan.

Kepada Kepala Sekolah Dasar No. 3 Kapal disarankan dalam pembelajaran siswa dipandang sebagai subjek yang aktif untuk mencari dan menemukan pengetahuan. Guru perlu lebih kreatif dalam merancang pembelajaran yang memberikan kesempatan kepada siswa untuk menemukan sendiri pengetahuan. 
Kepada peneliti lain yang ingin mendalami penerapan model pembelajaran kooperatif tipe NHT disarankan dapat melakukan penelitian yang lebih memadai. Misalnya penelitian tentang berbagai kendala yang terjadi dalam penelitian ini yang menyebabkan hasil belajar IPA belum optimal

\section{Daftar Pustaka}

Angga Wiguna, Sang Gede., I Wayan Widiana, Dewa Nyoman Sudana. Penerapan Pembelajaran Berbasis Otak Untuk Meningkatkan Kemampuan Pemecahan Masalah Matematika Siswa Kelas V Sekolah Dasar. Mimbar PGSD Vol 5 No 2 Tahun 2016. (http://ejournal.undiksha.ac.id/index.php/JJPGSD/ article/view/7776).

Agung, A.A Gede. 2010. Metedologi Penelitian Pendidikan. Singaraja: Aditya Media Publishing.

Agung, A.A. Gede. 2010. "Penelitian Konvensional (Eksperimental dan Non Eksperimental)”. Makalah disajikan dalam Workshop Jurusan Pendidikan Guru Sekolah Dasar FIP Undiksha. Jurusan Pendidikan Guru Sekolah Dasar FIP Undiksha. Singaraja 27 September 2010.

Agusditya, Putu Handy., I.G.A.A. Sri Asri, I Made Suara. The Effect of Scientific Approach Based on Portfolio Assessment towards the Learning Outcomes of Civic Education of the Students Grade V Viewed from the Tendency of Observing Objects on Theme 7 SDN 4 Ubung. Journal of Evaluation and Research in Education (JERE) Vol 1 No 1 Tahun 2017. (http://ejournal.undiksha.ac.id/ index.php/JERE/article/view/9842).

Agus Suarimbawa, Kadek., A. A. I. N. Marhaeni, GAP Suprianti. 2017. An Analysis of Authentic Assessment Implementation Based on Curriculum 2013 in SMP Negeri 4 Singaraja. Journal of Evaluation and Research in Education (JERE) Vol 1 No 1 Tahun 2017 (http://ejournal.undiksha.ac.id/ index.php/JERE/article/view/9551).

Arikunto, S DKK. 2010. Penelitian Tindakan Kelas. Jakarta : PT. Bumi Aksara.

Arikunto, Suharsimi. 2015. Penelitian Tindakan Kelas. Jakarta: Bumi Aksara

Aunurrahman. 2012. Belajar dan Pembelajaran. Bandung : Alfabeta.

Ayu Suryaningsih, Ni Made., I Made Elia Cahaya, Christiani Endah Poerwati. 2016. Implementasi Pembelajaran Inkuiri Terbimbing Berbasis Permainan Dalam Meningkatkan Kreativitas Anak Usia Dini. Jurnal Pendidikan Indonesia Vol 5. No 2 tahun 2016. (http://ejournal.undiksha.ac.id/ index.php/JPI/article/view/8559).

Dantes, Nyoman. 2012. Metode Penelitian. Yogyakarta : PT. Andi Yogyakarta.

Dina Hidayatul. 2012. Penerapan Model Pembelajaran Kooperatif Tipe Numbered Heads Together Untuk Meningkatkan Hasil Belajar Mata Pelajaran Ilmu Pengetahuan Alam. Journal. Universitas Pakuanhttps://www.google.com/url?sa=t\&rct=j\&q=\&esrc=s\&source=web\&cd=4\&cad=rja\&uact= 8\&ved=0ahUKEwiy3KqSur7TAhUBF5QKHT9aADkQFgg8MAM\&url=http\%3A\%2F\%2Fejournal.u ndiksha.ac.id\%2Findex.php\%2FJJPGSD\%2Farticle\%2Fdownload\%2F7622\%2F5197\&usg=AFQjC NE7cKyYyALBVkL_hnZPr5MRBdk_vA\&sig2=9yZ6UrHVcxYPoHoJR7yWmA

Elvin. 1999. Penerapan Pendekatan Pembelajaran Kooperatif dalam Upaya Meningkatkan Hasil Belajar Biologi Kelas 1 SLTP Negeri 6 Palu. Skripsi tidak diterbitkan. Palu : FKIP UNTAD.

Ibrahim, M, dkk. 2000. Pembelajaran Kooperatif. Surabaya : Universitas Negeri Surabaya.

Lie, dkk. 2004. Cooperative Learning. Jakarta : Grasindo.

Hadi, L. S., Agustriyana, Subagiyo Subagiyo. 2017. Project Based Learning on Casting of Aluminium Tensile Test Specimen for Mechanical Engineering Students, State Polytechnic of Malang on Odd Semester of Academic Year 2016/2017. Journal of Evaluation and Research in Education (JERE) Vol 1 No 1 Tahun 2017. (http://ejournal.undiksha.ac.id/ index.php/JERE/article/view/9844).

Januarti, Ni Ketut., I Ketut Dibia, I Wayan Widiana. 2016. Analisis Kesulitan Belajar Dalam Pembelajaran Membaca Cepat Siswa Kelas V Sd Gugus Vi Kecamatan Abang. Mimbar PGSD Vol 4 No 1 Tahun 2016. (http://ejournal.undiksha.ac.id/index.php/JJPGSD/ article/view/7442). 
Jasdilla. 2016. Hasil Belajar Dan Pembelajaran Kooperatif Tipe Think Pair Share (Tps). Journal Pendidikan Indonesia P-ISSN: 2303-288X E-ISSN: 2541-7207 Vol. 6, No.1, April 2016. http://ejournal.undiksha.ac.id/index.php/JPI/article/view/9253/6328

Lie, Anita (1999). Cooperatve Learning: Mempraktikan Cooperatve Learning di Ruang Kelas, Jakarta: Grasindo.

Laba Laksana, Dek Ngurah. 2016. Miskonsepsi Dalam Materi IPA Sekolah Dasar. Jurnal Pendidikan Indonesia Vol 6.No 2 tahun 2016. (http://ejournal.undiksha.ac.id/ index.php/JPI/article/view/8588).

Lasmawan Wayan. 2010. Menelisik Pendidikan IPS Dalam Perspektif Kontekstual dan Empiris. Singaraja : Mediakom Indonesia Press Bali.

Oka Sugiarta, Gst Pt., I Wayan Widiana, I Dewa Kade Tastra. Penerapan Model Pembelajaran Akselerasi (Accelerated Learning) Untuk Meningkatkan Hasil Belajar Ipa Siswa Kelas V di SD N 8 Banyuning. Mimbar PGSD Vol 6 No 3 Tahun 2016. (http://ejournal.undiksha.ac.id/index.php/JJPGSD/ article/view/8600).

Mitrawati. 2010. Meningkatkan Hasil Belajar IPA Melalui Pemanfaatan Lingkungan Sekolah Pada Siswa Kelas V SD Karya Thayyibah Baiya. artikel Sarjana pada FKIP Universitas Tadulako Palu: Tidak diterbitkan.

Nur, Muhammad, 2005. Pembelajaran Kooperatif. Surabaya: Pusat sains dan matematika sekolah UNESA.

Nur, Moh, dkk. 1996. Teori Pembelajaran IPA dan Hakekat Pendekatan KeterampilanProses. Bandung: Depdikbud, Direktorat Jendral Pendidikan Dasar dan Menengah.

Nursiyem. 2012. Meningkatkan Hasil Belajar IPA pada Materi Bagian Tumbuhan dan Fungsinya Melalui Penerapan Metode Kerja Kelompok Pada Siswa Kelas IV SD Inpres Tandaigi.Palu: Untad

Septiani Ari Pertiwi, Ni Luh., Ni Wayan Arini, I Wayan Widiana. 2016. analisis Tes Formatif Bahasa Indonesia Kelas IV Ditinjau Dari Taksonomi Bloom Revisi di Gugus XIII Kecamatan Buleleng Tahun Ajaran 2015/2016. Mimbar PGSD Vol 5 No 2 Tahun 2016. (http://ejournal.undiksha.ac.id/index.php/JJPGSD/article/view/7692).

Sudjana, N. 2000. Dasar-Dasar Proses Belajar Mengajar. Bandung : Sinar Baru Algesindo.

Suryanto. 2009. Evaluasi Pembelajaran di SD. Jakarta: Universitas Terbuka.

Trianto. 2007. Model Pembelajaran Terpadu dalam Teori dan Praktek. Jakarta: Prestasi Pustaka Publisher.

2009. Mendesain Model Pembelajaran Inovatif-Progresif: Konsep, Landasan, dan Implementasinya pada Kurikulum Tingkat Satuan Pendidikan (KTSP). Jakarta: Kencana.

Udani, Sri Naya Ketut. 2006. Penerapan Model Pembelajaran Kooperatif Tipe Numbered-Head-Togerher (NHT) untuk Meningkatkan Kreatifitas dan Pemahaman Konsep Matematika Siswa Kelas VIIC SMP N Negeri 2 Singaraja. Skripsi (Tidak Diterbitkan). Jurusan Pendidikan Matematika. UNDIKSHA Singaraja

Widiana, dkk. 2014. Pengaruh Model Pembelajaran Kooperatif Tipe Think Pair Square (Tps) Berbantuan Kartu Kerja Terhadap Hasil Belajar Matematika. Jurnal Mimbar PGSD Universitas Pendidikan Ganesha Jurusan PGSD (Vol: 2 No: 1 Tahun 2014).

Widiana, I Wayan. 2016. Pengembangan Asesmen Proyek Dalam Pembelajaran IPA di Sekolah Dasar. Jurnal Pendidikan Indonesia Vol 6.No 2 tahun 2016. (http://ejournal.undiksha.ac.id/ index.php/JPI/article/view/8154). 